\title{
Supratentorial Pleomorphic Xanthoastrocytoma
}

National Cancer Institute

\section{Source}

National Cancer Institute. Supratentorial Pleomorphic Xanthoastrocytoma. NCI

Thesaurus. Code C156041.

A pleomorphic xanthoastrocytoma that arises from the supratentorial region of the brain. 